Pittsburg State University

Pittsburg State University Digital Commons

7-19-2021

\title{
A Partnership Model for Preparing Educators for Successful Job Interviews.
}

Dawn Martin

drmartin@pittstate.edu

Follow this and additional works at: https://digitalcommons.pittstate.edu/coe_faculty

Part of the Educational Leadership Commons, and the Teacher Education and Professional Development Commons

\section{Recommended Citation}

Martin, D. (2021). A Partnership Model for Preparing Educators for Successful Job Interviews. Academia Letters, Article 2669. https://doi.org/10.20935/AL2669.

This Article is brought to you for free and open access by the College of Education at Pittsburg State University Digital Commons. It has been accepted for inclusion in Faculty Submissions by an authorized administrator of Pittsburg State University Digital Commons. For more information, please contact lfthompson@pittstate.edu. 


\section{ACADEMIA $\mid$ Letters}

\section{A Partnership Model for Preparing Educators for Successful Job Interviews}

Dawn Martin

\section{A Partnership Model for Preparing Educators for Successful Job Interviews}

Great variation exists in the quality of principal preparation programs (Fink, 2011). As a result, Fink recommends that districts develop capacity from within, using a grow your own approach (p. 681). He recommends that such programs allow future administrators to engage in real-world administrative duties under the guidance of mentor administrators. Busine and Watt (2005) also suggested that training potential leaders should include "specific job actions that involve on-the job assignments, coaching, and targeted training (p. 230). Fink (2011) further noted that, "the corporate world is increasingly following this model creating "corporate academies' that ... provide contextualized leadership development that focuses on developing leadership potential to ensure a continuing supply of quality leaders" (p. 677).

\section{Opportunities for Authentic Practice}

Darling-Hammond et al. (2010) point out that, "effective leadership preparation requires ongoing support across the trajectory of leadership roles, providing meaningful opportunities for leaders across the continuum of development to learn the instructional and leadership demands of the Region" (p. 48). Bryant, Escalante, and Selva (2017) argue that principals build leadership capacity by participating in opportunities for authentic administrative practice; moreover, "teachers viewed the opportunities to complete authentic administrative tasks 
as critical to their development as school administrators" (p. 37). DeWitt (2018) asserted that this must occur early in the recruitment process, so that candidates have realistic expectations of the role. Similarly, Leithwood et al. (2004) argue that:

The work of district and school leaders can be conceptualized as practical problem-solving, a type of thinking embedded in activity. A significant part of the learning required for such leaders to further develop their practical problem-solving expertise is usefully conceptualized as "situated." . . . Situated cognition requires leaders to be immersed in "authentic," nonroutine professional activity embedded in a supportive organizational culture. (pp. 67-68)

Practical experience increases the likelihood of success in the job and makes for a more attractive applicant. School Leaders Network (2014) identified commonalities among successful principal preparation programs:

These programs invest in careful selection of promising teacher leaders, extensive training in technical aspects of the job and accelerating leadership competency development. (p. 5)

Fuller and Young (2009) also emphasized the importance of identifying potential leaders and providing them with relevant training and experiences designed to prepare them to lead schools.

Darling-Hammond et al. (2007) also found that the success of exemplary principal preparation programs was influenced, in part, by partnerships. Bryant et al. (2007) recommended that, "The leadership academy should be a collaborative effort focused on helping principals develop promising practices" (pp. 39-40).

\section{A Case Study}

Greenbush Education Service Center has offered Leadership Academies since 1984. As of the Spring of 2020, there were over 1600 graduates of these programs. However, there appeared to be a disparity between the number of Academy graduates and the number of qualified applicants, as many graduates did not go on to complete their master's degree and obtain principal licensure.

In Kansas, a year of mentoring is required before novice administrators can move from an initial license to a professional license. Participation in Leadership Academy fulfills that requirement. Thus, with the reality of a shortage of available administrators, many Academy participants are already serving in their first leadership role.

In June 2018, Pittsburg State University Educational Leadership Faculty and staff from the Greenbush Education Service Center collaborated to form a partnership to enhance the Academy and expand opportunities to develop a pool of qualified future building administrators.

Corresponding Author: Dawn Martin,drmartin@pittstate.edu

Citation: Martin, D. (2021). A Partnership Model for Preparing Educators for Successful Job Interviews. Academia Letters, Article 2669. https : //doi .org/10.20935/AL2669. 
The Pittsburg State University/Greenbush Leadership Academy Partnership began in the fall of

2018. Beginning with the 2018-19 academic year, school superintendents were encouraged to

identify potential leaders and nominate them for participation in a dual Greenbush/PSU experience, based on the following premises:

1. Aspiring administrators who have practical application/experiences during study will be more effective once on the job.

2. Graduate on-line programs may be enhanced through face-to-face group discussions, simulations, and professional network-building. (Martin, 2019).

One of the areas in which authentic practice is offered is with the development of interviewing skills. Participants receive instruction and guided and independent practice in both roles: As interviewer and interviewee. Academy mentors provide instruction regarding, "Hiring the Best and Brightest," and "Making Yourself the Best Candidate." As potential hiring managers, participants learn to develop good interview questions, utilize good verbal and nonverbal skills for interviewing, critically review resumes and conduct reference checks. Participants practice their skills in simulation interviews. Simultaneously, faculty in the University's undergraduate program are working with student teachers to develop their skills as interviewees.

The culminating event for this module involves a mock interview fair in which the Leadership Academy participants (future administrators) set up booths marketing their districts and interview the students (future teachers) for potential openings. At the conclusion of the interview, each side gives the other feedback on what they did well and what they might do to improve their performance. This event precedes the "real" Teacher Interview Fair at the University, giving both sides valuable practice.

Feedback from this event has been overwhelmingly positive. Both administrative and teacher candidates report that this event increased their levels of confidence and improved their interview performance. In some cases, teacher candidates are actually offered teaching contracts at the mock fair.

Aspiring administrators and teachers benefit from this authentic practice. The University and Service Center also benefit. By pooling resources, candidates are provided access and opportunities beyond what is normally available, and the providers also benefit from the goodwill that has developed as a result; proving the old "TEAM" adage: "Together, We Can Achieve More."

Academia Letters, August 2021

C2021 by the author - Open Access — Distributed under CC BY 4.0

Corresponding Author: Dawn Martin,drmartin@pittstate.edu

Citation: Martin, D. (2021). A Partnership Model for Preparing Educators for Successful Job Interviews. Academia Letters, Article 2669. https : //doi .org/10.20935/AL2669. 


\section{References}

Bryant, J., Escalante, K., \& Selvin, A. (2017). Promising practices: Building the next generation of school leaders. Journal of School Administration Research and Development, 2(1), 32-41. Retrieved from https://files.eric.ed.gov/fulltext/EJ1158096.pdf

Busine, M., \& Watt, B. (2005). Succession management: Trends and current practices. Asia Pacific Journal of Human Resources, 43(2), 225-37. https://doi.org/10.1177/1038411105055060

Darling-Hammond, L., Myerson, D., LaPointe, M., \& Orr, M.T. (2010). Preparing principals for a changing world: Lessons from effective school leadership programs. San Francisco: Jossey-Bass.

DeWitt, P. (2018, September 30). How do we solve the administrator shortage? Retrieved from http://blogs.edweek.org/edweek/finding_common_ground/2018/09/educational_crisis__how_do_we_solve_the_administrator_shortage.html

Fink, D. (2011). Pipelines, pools and reservoirs: Building leadership capacity through succession management. London, England: SAGE Publications.

Fink, D. \& Brayman, C. (2006). School leadership succession and the challenges of change. Educational Administration Quarterly, 42(1), 62-89. https://doi.org/10.1177/0013161X05278186

Fuller, E., \& Young, M. D. (2009, May). Tenure and retention of newly hired principals in Texas. Texas High School Project: Leadership Initiative Issue Brief 1. Department of Educational Administration, The University of Texas at Austin. Austin, TX. Retrieved February 16, 2019, from https://www.researchgate.net/publication/228660740

Leithwood, K., Louis, K. S., Anderson, S., \& Wahlstrom, K. (2004). How leadership influences student learning [Review of research]. Minneapolis: University of Minnesota, Center for Applied Research and Educational Improvement. Retrieved from https://www .wallacefoundation.org/knowledge-center/Documents/How-Leadership-Influences-StudentLearning.pdf

Martin, Dawn R. (2019). Developing school building administrators to lead the next generation: A partnership between Pittsburg State University and Greenbush Education Service Center. AESA Perspectives. Retrieved from: https://www.aesa.us/blog/?p=321

Corresponding Author: Dawn Martin,drmartin@pittstate.edu Citation: Martin, D. (2021). A Partnership Model for Preparing Educators for Successful Job Interviews. Academia Letters, Article 2669. https : //doi .org/10.20935/AL2669. 
School Leaders Network. (2014). Churn: The high cost of principal turnover. Retrieved from https://www.acesconnection.com/fileSendAction/fcType/0/fcOid/405780286632981504/filePointer/ 405780286632981536/fodoid/405780286632981531/principal_turnover_cost.pdf

Corresponding Author: Dawn Martin,drmartin@pittstate.edu

Citation: Martin, D. (2021). A Partnership Model for Preparing Educators for Successful Job Interviews.

Academia Letters, Article 2669. https : //doi .org/10.20935/AL2669. 